\title{
Assessment of bacteria and SPM in the indoor air of households of urban area of Jammu (J\&K), India
}

\author{
Raj Kumar Rampal" and Neha Sharma \\ Department of Environmental Sciences, University of Jammu, Jammu (J\&K), INDIA \\ * Corresponding author.E-mail: rajkrampal@gmail.com
}

\begin{abstract}
The present study was conducted to assess status of bacteria (Gram +ve and Gram -ve) in the indoor air of Households located in Jammu city. The study area was divided into eight Sites. At each site two Households were selected randomly and in each Household sampling of SPM $\left(\mu \mathrm{g} / \mathrm{m}^{3}\right)$ and bacteria $\left(\mathrm{CFU} / \mathrm{m}^{3}\right)$ was done twice at three sub sites. Total bacterial count and SPM was found to be maximum (9308.24 CFU $/ \mathrm{m}^{3}$ and $\left.1006.12 \mu \mathrm{g} / \mathrm{m}^{3} \mathrm{respectively}\right)$

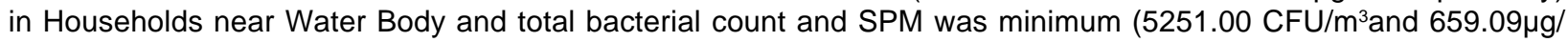
$\mathrm{m}^{3}$ respectively) in Households near Hospital. A significant positive correlation ( $r$ ) was found between SPM and no. of Gram +ve (+0.18 to +0.78$)$ as well as between SPM and no. of Gram -ve $(+0.21$ to +0.76$)$ bacteria in the study area.
\end{abstract}

Keywords: Household, Indoor SPM, Bacteria, Correlation

\section{INTRODUCTION}

Air pollutants are prime culprits responsible for polluting both indoor as well as outdoor environment. Indoor air quality refers to quality of air in buildings occupied spaces. It should be probably be called indoor air pollution. Our buildings have undergone radical changes over past few decades thereby resulting in less opportunity to exchange indoor air with outdoor air. This has led to concentration of air pollutants like dust, $\mathrm{CO}_{2}$, bacteria etc within the building (Purohit and Ranjan, 2005).

The causal agents of illness and stress can be of chemical, physical or biological origin and have a sizeable impact on productivity. Biological contamination of environment has received great attention in recent years as a possible cause of illness at home and at work place. The interrelationships of building materials, construction, services and spatial arrangements with their environment, occupants and contents are complex and can influence our health and comfort in buildings. Microorganisms are always present in outdoor air but their number and type's changes with time of day, weather, season, geographical location and with the presence of local spore sources (Nair et al. 1996).

Most people spend $90 \%$ of their time indoors. Indoor air quality plays a greater role in the health of people who spend most of their time indoors i.e. the very young, the very elderly and those who are chronically ill. Air inside homes, offices, schools and other buildings can be more polluted than outdoor air because heating; cooling and ventilation systems are common sources of bacterial as well as fungal growth.

The aim of present study is to assess the status of bacteria and SPM in the indoor air of Households of urban area of Jammu.

\section{MATERIALS AND METHODS}

The study area was divided into eight sites: Site I (Households located near G.B. Pant Hospital, Nai Basti), SiteII (Households in Commercial area, Jain Bazar), Site III (Households near National Highway I-A), Site IV (Households at Crossing, Satwari), Site V (Households in residential area but near Water Body, Jullaka Mohalla), Site VI (Households in residential area but near waste dumping site, Bhagwati Nagar), Site VII (Households in residential area but away from waste dumping site and big open drain, Sainik colony) and Site VIII (Households in residential area but near big open drain, Bakshi Nagar). At each site two households were selected randomly and in each household sampling of SPM and bacteria $\left(\mathrm{CFU} / \mathrm{m}^{3}\right)$ was done twice (i.e. once during July-Sept.2008 and once during Oct.-Dec.2008) at three sub sites i.e. Bedroom, Kitchen and Drawing room. Average value of each parameter with standard deviation for an average household at each site was compiled from data of twelve readings in a period of six months. Correlation coefficients (r) between SPM and gram +ve coccus, SPM and gram+ve bacillus, SPM and total numbers of Gram+ve bacteria, SPM and gram +ve coccus, SPM and gram+ve bacillus, SPM and total numbers of Gram -ve bacteria, SPM and total number of Coccus, SPM and total number of Bacillus 
at all sites of study area were calculated using Pearson product-moment method.

Air Sampling for SPM was done by using Handy Air Sampler Envirotech APM 821 for two hours at a height of $5 \mathrm{ft}$ above the ground. SPM was determined by formula:-

$$
\operatorname{SPM}\left(\mu \mathrm{g} / \mathrm{m}^{3}\right)=\frac{\left(\mathrm{W}_{2}-\underline{\mathrm{W}}_{1}\right) \times 10^{3}}{\mathrm{~T} \times \underline{\mathrm{R}}_{\frac{1}{2}+\mathrm{R}_{2}}}
$$

Where $\mathrm{W}_{1}$ and $\mathrm{W}_{2}=$ initial and final weight of filter paper, $R_{1}$ and $R_{2}=$ initial and final flow rate in cubic metre.

$\mathrm{T}=$ sampling time in minutes

Air sampling for bacteria was done using Handy Air Sampler Envirotech APM 821 for 10 min at a height of $5 \mathrm{ft}$ above the ground using sterile impingers containing 6 $\mathrm{ml}$ of distilled water. Three Petri plates i.e. one with Nutrient agar (peptic digest of animal tissue, beef extract, yeast extract, sodium chloride, agar, $\mathrm{pH} 7.4 \pm 0.2$ ), second with MacConkey agar (peptic digest of animal tissue, lactose, sodium taurocholate, neutral red, agar, $\mathrm{pH}$ 7.4 \pm 0.2 ) and third with BTB Lactose agar (proteose peptone, beef extract, lactose, bromo thymol blue, agar, $\mathrm{pH} 8.6 \pm 0.2$ ) were inoculated with $2 \mathrm{ml}$. of impinged water from each impinger in Laminar flow and incubated at $37^{\circ} \mathrm{C}$ for $48 \mathrm{hrs}$ in bacteriology incubator.

The quantification of bacterial count was done by using the formula:-

No. of microbes per volume $(1)=$

No. of microbes collected by impinger of air (CFU $/ \mathrm{m}^{3}$ ) Volume of air

No. of microbes collected by impinger $=$ Sum total number. of colonies in all the three plates

Volume of air $=$ Sampling time $\mathrm{x}$ flow rate of air in litre per minute

Sampling of bacteria was also done directly by exposing Petri plates with above said media to ensure that all the existing bacteria have been impinged. Bacterial study from each colony was carried out using Gram's staining technique under immersion oil. A control set for each culture media was prepared and the colonies found growing on the culture Medias were subtracted from the respective exposed culture Medias.

\section{RESULTS AND DISCUSSION}

The analysis of data revealed that Households near Hospital (Site I) exhibited minimum indoor SPM of $659.09 \pm 253.23 \mu \mathrm{g} / \mathrm{m}^{3}$ whereas Households near Water body (Site V) exhibited maximum indoor SPM of $1006.12 \pm 224.95 \mu \mathrm{g} / \mathrm{m}^{3}$. The Drawing room of Households in residential area away from waste dumping site and big open drain (Site VII) exhibited minimum indoor SPM of $224.46 \mu \mathrm{g} / \mathrm{m}^{3}$ whereas Kitchen of the household at Site II i.e. in Commercial area exhibited maximum indoor SPM of $1560.54 \mu \mathrm{g} / \mathrm{m}^{3}$ (Table I).

The Household located in Site II i.e. in Commercial area exhibited minimum $1216.66 \mathrm{CFU} / \mathrm{m}^{3}$ count of Gram +ve cocci whereas Households in residential area but near Water Body i.e. Site V exhibited maximum value of 2448.31 $\mathrm{CFU} / \mathrm{m}^{3}$ count. Gram +ve bacilli exhibited maximum value of $2842.82 \pm 2062.08 \mathrm{CFU} / \mathrm{m}^{3}$ in households located in Commercial area and minimum value of $1168.58 \pm 343.37$ $\mathrm{CFU} / \mathrm{m}^{3}$ in Households located near National Highway I -A (Table I).

The Households at site I i.e. Near Hospital exhibited minimum Gram-ve cocci count of 1172.05 $\pm 327.32 \mathrm{CFU} /$ $\mathrm{m}^{3}$ and Households located Near Water Body (Site V) exhibited maximum value of $2409.77 \pm 1474.20 \mathrm{CFU} / \mathrm{m}^{3}$. Gram-ve bacilli exhibited maximum and minimum values of $2475.01 \pm 1006.48 \mathrm{CFU} / \mathrm{m}^{3}$ and $1137.40 \pm 477.47 \mathrm{CFU} / \mathrm{m}^{3}$ at Site V i.e. Households Near Water Body and Site I i.e. Households Near Hospital (Table I), respectively.

The total average count of bacteria in the indoor air exhibited minimum value of $5251.00 \pm 1164.81 \mathrm{CFU} / \mathrm{m}^{3}$ with $56.01 \%\left(2941.55 \pm 1021.10 \mathrm{CFU} / \mathrm{m}^{3}\right)$ of Gram +ve and $43.98 \%$ (2309.45 \pm 795.27 ) of Gram -ve bacteria at Site I i.e. Households Near Hospital and maximum value of $9308.24 \pm 2789.84 \mathrm{CFU} / \mathrm{m}^{3}$ with $47.52 \%(4423.46 \pm 1161.31)$ of Gram +ve and $52.48 \%(4884.77 \pm 1952.09)$ Gram -ve bacteria at Site V i.e. Households Near Water Body. Overall analysis at different sites of study area revealed that Households in the study area exhibited average indoor SPM of 801.25 \pm 300.73 with range of 224.46-1560.54. Analysis of data further revealed that Gram +ve and Gram -ve bacteria exhibited average bacterial count of $3552.30 \pm 1653.86$ with a range of 821.21-10555.54 and $3246.14 \pm 1729.75$ with a range of 1135.41-9062.5, respectively (Table I).

The critical analysis of the data revealed that Site $\mathrm{V}$ i.e. Households Near Water Body and Site VII i.e. Households in residential area away from waste dumping site and big open drain exhibited high \%age of Gram-ve bacteria whereas the rest of the Sites viz. Site I i.e. (Households located near Hospital), Site II ( Households in Commercial area), Site III (Households near National Highway I-A), Site IV ( Households at Crossing), Site VI (Households in residential area but near waste dumping site), and Site VIII( Households in residential area but near big open drain )exhibited high \%age of Gram +ve bacteria.

Overall analysis of data revealed that Households near Hospital surprisingly exhibited minimum indoor SPM and also the minimum value of bacterial count which might be due to maintenance of best sanitation conditions whereas Site V (. Households near Water Body) exhibited maximum indoor SPM as well as maximum value of bacterial count due to dumping of silting material on banks of water body (Table I). Subba Rao et al. (1988) and Subramanyam et al. (1991) while studying microbial air quality of Madras city reported that increase in concentration of $\mathrm{SO}_{2}$ and $\mathrm{NOx}$ decreased microbial 
Table 1. Indoor SPM and bacteria in households at different sites in Jammu city.

\begin{tabular}{|c|c|c|c|c|c|c|c|c|}
\hline \multirow{3}{*}{ Households } & \multirow{3}{*}{$\begin{array}{l}\text { Indoor SPM } \\
\qquad\left(\mathbf{u g} / \mathbf{m}^{3}\right)\end{array}$} & \multicolumn{6}{|c|}{ No. of bacteria $\left(\mathrm{CFU} / \mathrm{m}^{3}\right)$ in Indoor Air } & \multirow[b]{3}{*}{$\begin{array}{l}\text { Grand } \\
\text { Total }\end{array}$} \\
\hline & & \multicolumn{4}{|c|}{ Gram+ve } & \multicolumn{2}{|l|}{ Gram-ve } & \\
\hline & & Coccus & Bacillus & Total & Coccus & Bacillus & Total & \\
\hline SiteI & $\begin{array}{c}659.09 \pm 253.23 \\
(293.16-1054 \\
.85)\end{array}$ & $\begin{array}{c}1771.26 \pm 77 \\
0.28(842.1- \\
3176.46)\end{array}$ & $\begin{array}{c}1170.30 \pm 3 \\
59.01 \\
(718.75- \\
1789.47)\end{array}$ & $\begin{array}{c}2941.55 \pm 1 \\
021.10 \\
(1883.33- \\
4941.16)\end{array}$ & $\begin{array}{c}1172.05 \pm 3 \\
27.32 \\
(789.47- \\
1529.41)\end{array}$ & $\begin{array}{l}1137.40 \pm \\
477.47 \\
(555.55- \\
2368.41)\end{array}$ & $\begin{array}{c}2309.45 \pm 7 \\
95.27(13 \\
45.02- \\
4268.41)\end{array}$ & $\begin{array}{c}5251.00 \pm \\
1164.81 \\
(3744.78- \\
7464.88)\end{array}$ \\
\hline SiteII & $\begin{array}{c}900.04 \pm 326.93 \\
(446.22-1560 \\
.54)\end{array}$ & $\begin{array}{c}1216.66 \pm 48 \\
1.80(473.68 \\
-1852.94)\end{array}$ & $\begin{array}{c}2842.82 \pm 2 \\
062.08(113 \\
4.44- \\
8888.88)\end{array}$ & $\begin{array}{c}4059.48 \pm 2 \\
269.26 \\
(2036.18- \\
10555.54)\end{array}$ & $\begin{array}{c}1947.44 \pm 1 \\
013.13(777 \\
.77- \\
4219.51)\end{array}$ & $\begin{array}{c}1745.06 \pm 8 \\
39.45(777 \\
77-3809 . \\
52)\end{array}$ & $\begin{array}{c}3692.50 \pm 1 \\
525.26 \\
(2444.43- \\
8020.03)\end{array}$ & $\begin{array}{c}7751.98 \pm \\
3060.77 \\
(5346.72- \\
14836.81)\end{array}$ \\
\hline SiteIII & $\begin{array}{c}707.79 \pm 239.07 \\
(292.39-1054 \\
85)\end{array}$ & $\begin{array}{c}1746.64 \pm 97 \\
2.87(555.55 \\
-3684.20)\end{array}$ & $\begin{array}{c}1168.58 \pm 3 \\
43.37(833 . \\
33-189 \\
4.73)\end{array}$ & $\begin{array}{c}2915.22 \pm 1 \\
218.83 \\
(1449.66- \\
5578.93)\end{array}$ & $\begin{array}{c}1243.18 \pm 4 \\
48.01(546 . \\
29-164 \\
7.05)\end{array}$ & $\begin{array}{c}1316.27 \pm 6 \\
32.67(555 \\
55-2631 \\
57)\end{array}$ & $\begin{array}{c}2559.45 \pm 1 \\
046.92 \\
(1620.36- \\
4531.57)\end{array}$ & $\begin{array}{c}5474.67+ \\
1637.57 \\
(3126.73- \\
8736.81)\end{array}$ \\
\hline SiteIV & $\begin{array}{c}859.02 \pm 160.63 \\
(586.33-1054 \\
.85)\end{array}$ & $\begin{array}{l}1616.65 \pm 73 \\
9.15(555.55 \\
-3078.94)\end{array}$ & $\begin{array}{c}1593.16 \pm 7 \\
83.97 \\
(894.11- \\
3411.75)\end{array}$ & $\begin{array}{c}3209.81 \pm 1 \\
113.39( \\
2326.3- \\
4993.98)\end{array}$ & $\begin{array}{c}1541.46 \pm 7 \\
19.94(777 . \\
77-3000)\end{array}$ & $\begin{array}{c}1212.03 \pm 4 \\
86.48(555 . \\
55-2368 \\
.41)\end{array}$ & $\begin{array}{c}2753.49 \pm 1 \\
043.83 \\
(1345.02- \\
4268.41)\end{array}$ & $\begin{array}{c}5963.30 \pm \\
1277.56 \\
(4423.51- \\
7528.66)\end{array}$ \\
\hline SiteV & $\begin{array}{c}1006.12 \pm 224.9 \\
5(624.21-139 \\
3.24)\end{array}$ & $\begin{array}{c}2448.31 \pm 11 \\
52.39(789.4 \\
6-3999.99\end{array}$ & $\begin{array}{c}1975.15 \pm 7 \\
08.64(1052 \\
.63-3000)\end{array}$ & $\begin{array}{c}4423.46 \pm 1 \\
161.31 \\
(2158.72- \\
5541.66)\end{array}$ & $\begin{array}{c}2409.77 \pm 1 \\
474.20 \\
(833.33- \\
6562.5)\end{array}$ & $\begin{array}{c}2475.01 \pm 1 \\
006.48 \\
(1291.66- \\
4875)\end{array}$ & $\begin{array}{c}4884.77 \pm 1 \\
952.09 \\
(2799- \\
9062.5)\end{array}$ & $\begin{array}{c}9308.24 \pm \\
2789.84 \\
(5161.73- \\
14687.5)\end{array}$ \\
\hline SiteVI & $\begin{array}{c}778.56 \pm 343.78 \\
(293.16-1251 \\
95)\end{array}$ & $\begin{array}{c}2222.82 \pm 10 \\
86.80(842.1 \\
-3999.99)\end{array}$ & $\begin{array}{c}1455.54 \pm 6 \\
68.35(718 \\
75-3000)\end{array}$ & $\begin{array}{c}3678.37 \pm 1 \\
371.31 \\
(1883.33- \\
5062.5)\end{array}$ & $\begin{array}{c}1343.71 \pm 5 \\
43.27(833 . \\
33-2250)\end{array}$ & $\begin{array}{c}1802.34 \pm 8 \\
85.62(647 . \\
05-3250)\end{array}$ & $\begin{array}{c}3146.06 \pm 1 \\
294.37 \\
(1489.15- \\
5277.76)\end{array}$ & $\begin{array}{c}6824.42 \pm \\
2202.47 \\
(3744.78- \\
10562.5)\end{array}$ \\
\hline SiteVII & $\begin{array}{c}799.29+303.00 \\
(224.46-1393 \\
.24)\end{array}$ & $\begin{array}{c}1608.55 \pm 11 \\
22.34(240.3 \\
4-3875)\end{array}$ & $\begin{array}{c}1790.72 \pm 9 \\
68.35(368 \\
42-3000)\end{array}$ & $\begin{array}{c}3399.27 \pm 1 \\
807.76 \\
(821.21- \\
5250)\end{array}$ & $\begin{array}{c}1944.23 \pm 1 \\
735.77 \\
(468.75- \\
6562.5)\end{array}$ & $\begin{array}{c}1740.98+1 \\
173.23(666 \\
.66-4875)\end{array}$ & $\begin{array}{c}3685.21 \pm 2 \\
584.58( \\
1135.41- \\
9062.5)\end{array}$ & $\begin{array}{c}7084.47 \pm \\
4127.15 \\
(2441 . .54- \\
14687.5)\end{array}$ \\
\hline SiteVIII & $\begin{array}{c}700.12+403.86 \\
(293.16-1560 \\
.54)\end{array}$ & $\begin{array}{c}1371.26 \pm 68 \\
4.09(473.68 \\
-3176 . \\
46)\end{array}$ & $\begin{array}{c}2419.96 \pm 2 \\
220.61(718 \\
.75- \\
8888.88)\end{array}$ & $\begin{array}{c}3791.22 \pm 2 \\
426.14 \\
(1883.33- \\
10555.54)\end{array}$ & $\begin{array}{c}1578.03 \pm 9 \\
75.82(842 . \\
10-4210 \\
.51)\end{array}$ & $\begin{array}{c}1670.43 \pm 8 \\
96.39(647 \\
05-3809 \\
.52)\end{array}$ & $\begin{array}{c}3248.46 \pm 1 \\
767.17 \\
(1489.15- \\
8020.03)\end{array}$ & $\begin{array}{c}7039.68 \pm \\
3445.68 \\
(3744.78- \\
14836.81)\end{array}$ \\
\hline Average & $\begin{array}{c}801.25 \pm 300.73 \\
(224.46-1560 \\
.54)\end{array}$ & $\begin{array}{c}1750.27 \pm 95 \\
6.02(661.76 \\
-8888.88)\end{array}$ & $\begin{array}{c}1802.03 \pm 1 \\
301.35 \\
(473.68- \\
3437.5)\end{array}$ & $\begin{array}{c}3552.30 \pm 1 \\
653.86 \\
(821.21- \\
10555.54)\end{array}$ & $\begin{array}{c}1647.48 \pm 1 \\
058.00 \\
(546.29- \\
6562.50)\end{array}$ & $\begin{array}{c}1637.44 \pm 8 \\
98.41 \\
(555.55- \\
4875)\end{array}$ & $\begin{array}{c}3246.14 \pm 1 \\
729.75 \\
(1135.41- \\
9062.5)\end{array}$ & $\begin{array}{l}6837.22 \pm \\
2869.86 \\
(2441.54- \\
14836.81)\end{array}$ \\
\hline
\end{tabular}

Site I (Households located near G.B. Pant Hospital, Nai Basti), Site II (Households in Commercial area, Jain Bazar), Site III (Households near National Highway I-A), Site IV (Households at Crossing, Satwari), Site V (Households in residential area but near Water Body, Jullaka Mohalla), Site VI (Households in residential area but near waste dumping site Bhagwati Nagar), Site VII (Households in residential area but away from waste dumping site and big open drain, Sainik colony) and Site VIII (Households in residential area but near big open drain, Bakshi Nagar).

content of air whereas increase in SPM values also increased the microbial content.

A significant correlation (r) was found between SPM and gram + ve coccus ( +0.13 to +0.66$)$, SPM and gram+ve bacillus $(+0.04$ to +0.70$)$, SPM and total numbers of Gram+ve bacteria $(+0.18$ to +0.78$)$, SPM and gram - ve coccus $(+0.06$ to +0.63$)$, SPM and gram-ve bacillus $(+0.33$ to +0.82$)$, SPM and total numbers of Gram -ve bacteria $(+0.21$ to +0.76$)$, SPM and total number of Coccus $(+0.21$ to +0.73$)$, and SPM and total number of Bacillus $(+0.33$ to +0.81$)$ at all sites of study area (Table II). Mancinelli and Shulls (1978), Subramanyam et al. (1999) also observed positive correlation between bacteria and SPM while studying airborne bacteria in urban 
Table 2. Correlation coefficients ( $r$ ) of bacteria and spm at different sites of Jammu city.

\begin{tabular}{|c|c|c|c|c|c|c|c|c|}
\hline \multirow{2}{*}{$\begin{array}{l}\text { SPM in households } \\
\text { at different Sites }\end{array}$} & \multicolumn{2}{|c|}{ Number of Gram+ve } & \multirow{2}{*}{$\begin{array}{c}\text { Total } \\
\text { Number } \\
\text { of } \\
\text { Gram+ve }\end{array}$} & \multirow{2}{*}{$\begin{array}{l}\text { Number of } \\
\text { Coccus }\end{array}$} & \multirow{2}{*}{$\begin{array}{l}\text { Gram-ve } \\
\text { Bacillus }\end{array}$} & \multirow{2}{*}{$\begin{array}{c}\text { Total } \\
\text { Number } \\
\text { of } \\
\text { Gram-ve }\end{array}$} & \multirow{2}{*}{$\begin{array}{c}\text { Total } \\
\text { Number } \\
\text { of coccus }\end{array}$} & \multirow{2}{*}{$\begin{array}{c}\text { Total } \\
\text { Number } \\
\text { of } \\
\text { Bacillus }\end{array}$} \\
\hline & Coccus & Bacillus & & & & & & \\
\hline SPM at Site I & +0.42 & +0.04 & +0.35 & +0.37 & +0.47 & +0.43 & +0.58 & +0.42 \\
\hline SPM at Site II & +0.33 & +0.27 & +0.31 & +0.49 & +0.54 & +0.62 & +0.50 & +0.41 \\
\hline SPM at Site III & +0.54 & +0.40 & +0.54 & +0.34 & +0.36 & +0.36 & +0.62 & +0.48 \\
\hline SPM at Site IV & +0.41 & +0.15 & +0.18 & +0.44 & +0.39 & +0.46 & +0.36 & +0.33 \\
\hline SPM at Site V & +0.31 & +0.22 & +0.44 & +0.06 & +0.33 & +0.21 & +0.21 & +0.40 \\
\hline SPM at Site VI & +0.56 & +0.46 & +0.67 & +0.42 & +0.82 & +0.74 & +0.73 & +0.81 \\
\hline SPM at Site VII & +0.66 & +0.70 & +0.78 & +0.51 & +0.57 & +0.61 & +0.60 & +0.75 \\
\hline SPM at Site VIII & +0.13 & +0.51 & +0.50 & +0.63 & +0.82 & +0.76 & +0.60 & +0.69 \\
\hline
\end{tabular}

Pearson product-moment correlation coefficients are given for each bacterial i.e.total number of gram+ve (coccus and bacillus), total number of gram-ve (coccus and bacillus), total number of coccus and total number of bacillus and SPM pair.

Site I (Households located near G.B. Pant Hospital, Nai Basti), Site II (Households in Commercial area, Jain Bazar), Site III (Households near National Highway I-A), Site IV (Households at Crossing, Satwari), Site V (Households in residential area but near Water Body, Jullaka Mohalla), Site VI (Households in residential area but near waste dumping site Bhagwati Nagar), Site VII (Households in residential area but away from waste dumping site and big open drain, Sainik colony) and Site VIII (Households in residential area but near big open drain, Bakshi Nagar).

environment.

The present study also revealed that bacterial count in indoor air is affected more by indoor sources of pollutants than outdoor sources of pollutants .The bacteria enter air and disperse into air from various sources. The survival of these bacteria is a function of weather and the chemical composition of air. There was a statistically significant correlation ( $r$ ) between the total number of bacteria and the concentrations of suspended particulate matter. It is reasonable to assume that bacteria in the air are protected from harsh environmental conditions, such as drying, by some of the suspended particulate matter (Mancinelli and Shulls, 1978).

The fluctuation in the number of Gram +ve Cocci and Bacilli as well as number of Gram -ve Cocci and Bacilli exhibited no set pattern of increase or decrease as it also depends on relative humidity, temperature and chemical pollutants. Mancinelli and Shulls (1978), also reported significant correlation between relative humidity and total number of bacilli but observed no correlation between relative humidity and total number of cocci.

\section{REFERENCES}

Mancinelli, R.L. and Shulls, W.A. (1978). Airborne bacteria in an urban environment. Applied and Environment Microbiology, 35(6):1095-1101.

Nair, M.V., Gupta, S. and Srivastava, A.K. (1996). Environmental Bio pollutants and Human Health. Anmol Publications Pvt.Ltd.

Purohit, S.S. and Ranjan, R. (2005). Ecology, Environment and Pollution. Agrobios Publications (India).

Subba Rao, K., Subramanyam, Y.V., Jayabalou, R., Patil, M.D. and Raguraman, D.(1988). Microbial air quality of Madras city. IAWPC Technical Annual, 15: 186- 191.

Subramanyam, Y.V., Subba Rao, K., Jayabalou., R. (1991). Study of the effect of air Pollutants on the air microbes at madras city (India). Asian Environment, 13(2):68-80.

Subramanyam, Y.V., Subba Rao, K., Jayabalou, R. and Jothikumar, N. (1999). Diurnal variation of air microbes with respect to respirable particulate matter $\left(\mathrm{PM}_{10}\right)$ in Chennai city. J. Indian Assoc. Environ. Manag., 26: 54-63. 